\title{
Sarcoidosis Presenting as an Intramedullary Spinal Cord Lesion
}

\author{
F.B. Maroun, F.J. O’Dea, G. Mathieson, G. Fox, G. Murray, \\ J.C. Jacob, R. Reddy, R. Avery
}

\begin{abstract}
Objectives: Sarcoidosis affects the spinal cord in only $0.43 \%$ of patients with sarcoidosis. Usually there is systemic involvement prior to the development of cord lesions. We present a case of sarcoid isolated to the intramedullary spinal cord, which was a diagnostic and therapeutic challenge. We review the case and then present a review of the literature with an emphasis on presentation, diagnosis and treatment. Methods: We have reviewed a patient who presented with an isolated sarcoid granuloma affecting the cervical spinal cord. All pertinent history and physical information was extracted from the patient's chart and through patient interview. Laboratory, radiographic and pathological investigations are presented. Results and conclusions: Fourteen patients have been reported with isolated intramedullary spinal cord sarcoidosis. Current practice supports the role of surgery for biopsy; mainstay of treatment is corticosteroids.
\end{abstract}

\begin{abstract}
RÉSUMÉ: Lésion intramédullaire comme mode de présentation initial d'une sarcoïdose. Objectifs: La moelle épinière est impliquée dans la sarcoïdose chez seulement $0.43 \%$ des patients atteints de cette maladie. Il y a habituellement des lésions systémiques avant l'apparition de lésions de la moelle épinière. Nous présentons un cas de lésion sarcoïdosique intramédullaire isolée, ce qui représente un défi diagnostique et thérapeutique. Nous revoyons le cas et nous présentons une revue de la littérature en soulignant le mode de présentation, le diagnostic et le traitement. Méthodes: Nous revoyons le cas d'un patient porteur d'un granulome sarcoïdosique isolé de la moelle épinière cervicale. L'histoire médicale pertinente et les données de l'examen physique ont été tirés du dossier du patient ainsi que d'une entrevue avec le patient. Nous présentons l'investigation biochimique, radiologique et anatomopathologique. Résultats et conclusions: Quatorze patients porteurs d'une sarcoïdose localisée uniquement à la moelle épinière ont été rapportés dans la littérature. La chirurgie a un rôle à jouer dans le diagnostic et la corticothérapie constitue la base du traitement.
\end{abstract}

Can. J. Neurol. Sci. 2001; 28: 163-166

Sarcoidosis is a multisystem granulomatous disease. Five to ten percent of patients with systemic sarcoid may have intracranial manifestations; involvement of spinal cord is rare. ${ }^{1-3}$ Spinal cord sarcoidosis may present as multiple (cord) lesions, diffuse leptomeningeal involvement, in the clinical context of systemic sarcoidosis. There are few case reports of intramedullary spinal cord sarcoidosis, without evidence of systemic sarcoidosis; less than $0.5 \%$ of patients have this clinical presentation. ${ }^{4}$ We report a patient with an isolated intramedullary cervical spinal cord sarcoid granuloma, who had no evidence of systemic sarcoidosis, and also review relevant literature.

\section{CASE REPORT}

A 42-year-old man presented with clinical features of cervical myelopathy. His large physique (weight 150kg; height $180.34 \mathrm{~cm}$ ) precluded magnetic resonance imaging (MRI); as no MRI system in Canada could accommodate an individual of his stature. Myelogram revealed extradural cord compression at mid-cervical spinal level C5C6. Cervical cord decompression, by laminectomy at C4-C7 spinal level resulted in marked improvement in clinical deficit; mild residual spasticity in lower limbs did not interfere with his functional abilities.

Four years later, a fall while dancing was followed by acute onset of weakness of right arm and marked spastic paraplegia; bladder and bowel function was unimpaired. Cervical cord trauma was clinically suspected; treatment with a high dose of Decardon resulted in clinical improvement. However, this improvement was short-lived, as the clinical deficits worsened when steroid dose was decreased. Magnetic resonance imaging, (obtained in the USA) revealed an oval enhancing lesion at C5-C6 (Figure 1, 2). Differential diagnosis included intramedullary cervical cord neoplasm, lupus, Lyme disease, granulomatous disease and post-traumatic myelomalacia. Following

From the Division of Neurosurgery, Neurology, Departments of Radiology and Pathology, Memorial University of Newfoundland, Health Sciences Centre, St. John's, Newfoundland, Canada

ReCeived August 21, 2000. ACCePted In Final Form DeCember 5, 2000. Reprint requests to: F.B. Maroun, Rm. 5202, Health Sciences Centre, St. John's, NF, Canada A1B 3V6 


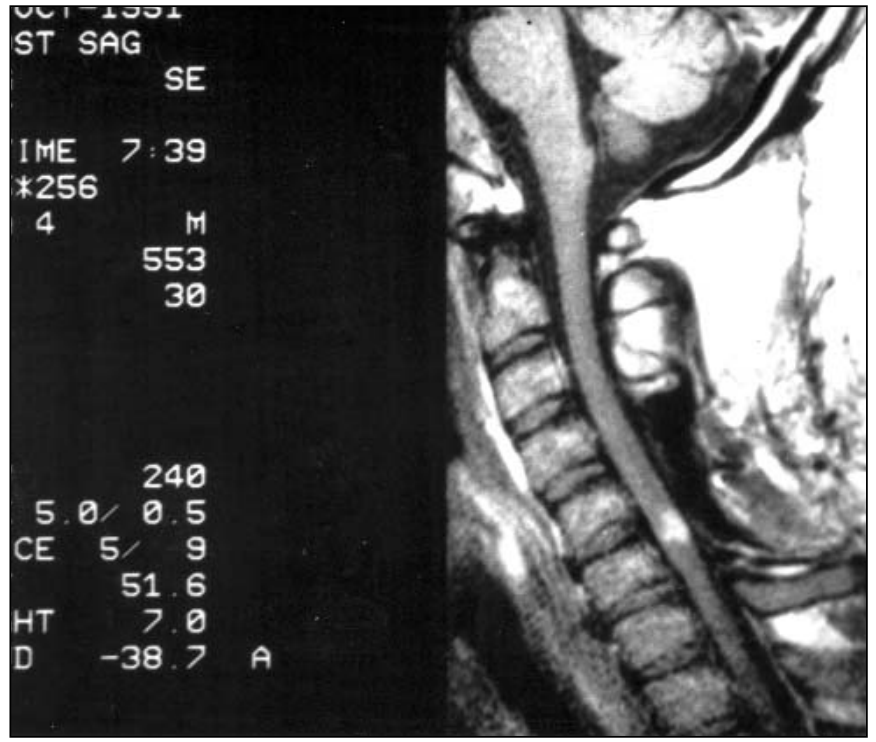

Figure 1: T1 weighted MRI image with gadolinium enhancement of well circumscribed lesion at the level of C5-C6. Note the intramedullary location of the lesion.

further cranial and spinal MRI, surgical biopsy of the lesion was performed, through the previous laminectomy site (Figure 3). The lesion was firm in consistency, easily distinguishable from neural tissue, but was poorly demarcated in its deeper margins.

Histopathologic examination of the biopsy revealed a granulomatous lesion. The lesion was composed of Langerhans cells, epitheloid cells and lymphocytes, with a peripheral rim of mononuclear cells (Figure 4). There was no evidence of necrosis, caseation, foreign body, fungi, or acid fast bacilli. There was no growth of fungus or acid fast bacilli on culture. Following histologic diagnosis of sarcoidosis, despite extensive investigation, there was no evidence of systemic sarcoidosis.

High dose prednisone therapy (60 mg od) was initiated together with rehabilitative therapy. Three months after biopsy, there was modest

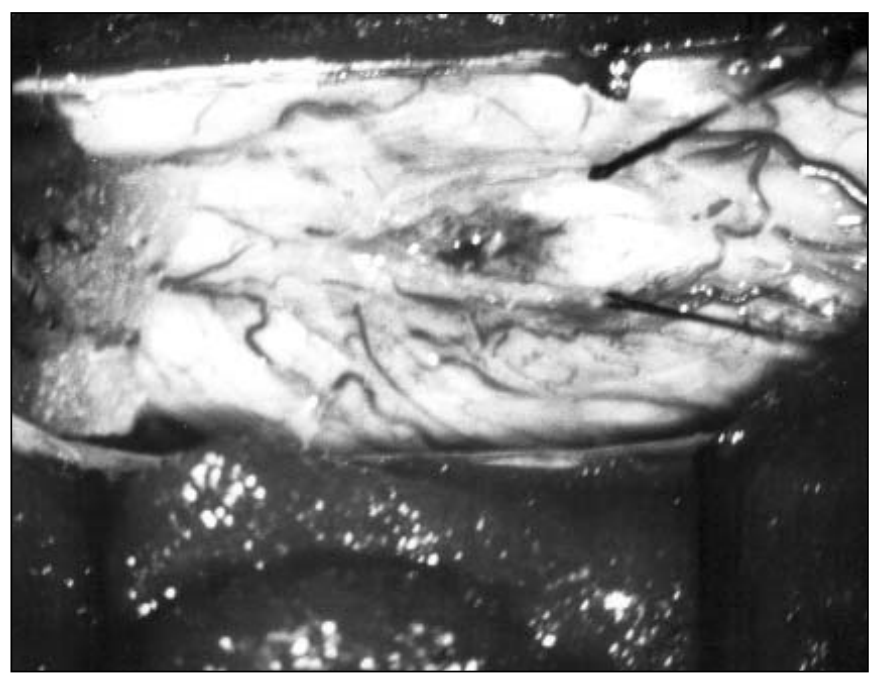

Figure 3: Operative photograph. Slight greyish discolorization of the spinal cord, intramedullarly removal of the circumscribed lesion.

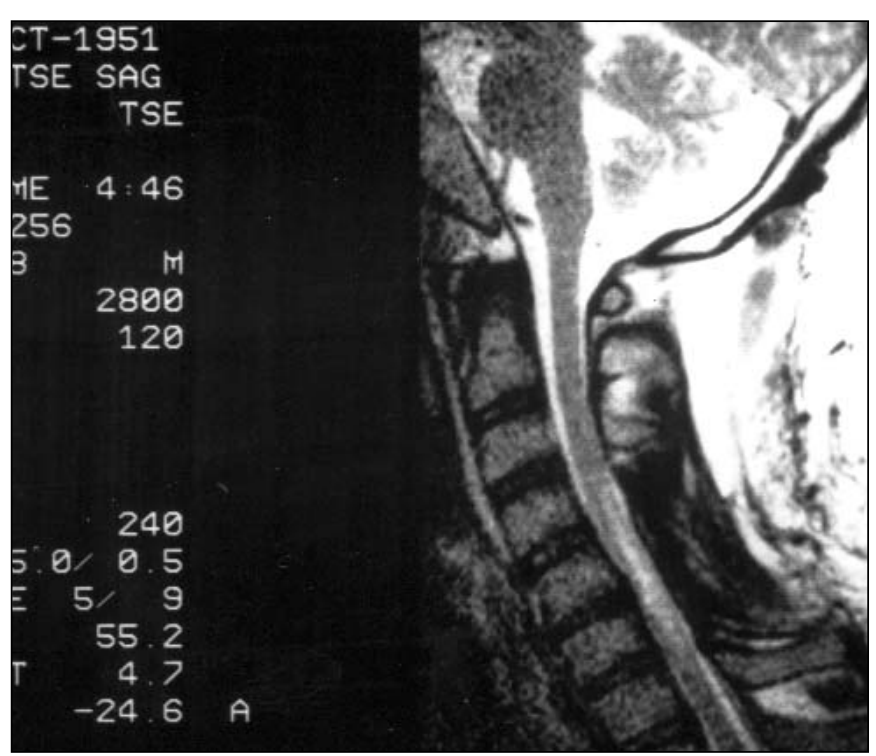

Figure 2: T2 weighted MRI image of the spinal cord lesion. Note that the lesion appears to involve the spinal cord more diffusely.

improvement in function of the right arm but only minimal improvement in sensation and power in lower limbs. Adverse effects of steroid treatment included weight gain, and insulin dependent diabetes mellitus.

\section{Discussion}

Thirty-seven cases of biopsy proved spinal cord sarcoidosis have been published. ${ }^{1,5-35}$ Of these, 20 had evidence of systemic sarcoidosis. ${ }^{7-17,21,24,27,28,30,31,33,36-51}$ Fourteen patients presented with an isolated intramedullary spinal cord sarcoid granuloma (Table).

The cervical cord is the site of predilection for spinal sarcoidosis; however, the mode of presentation is variable.

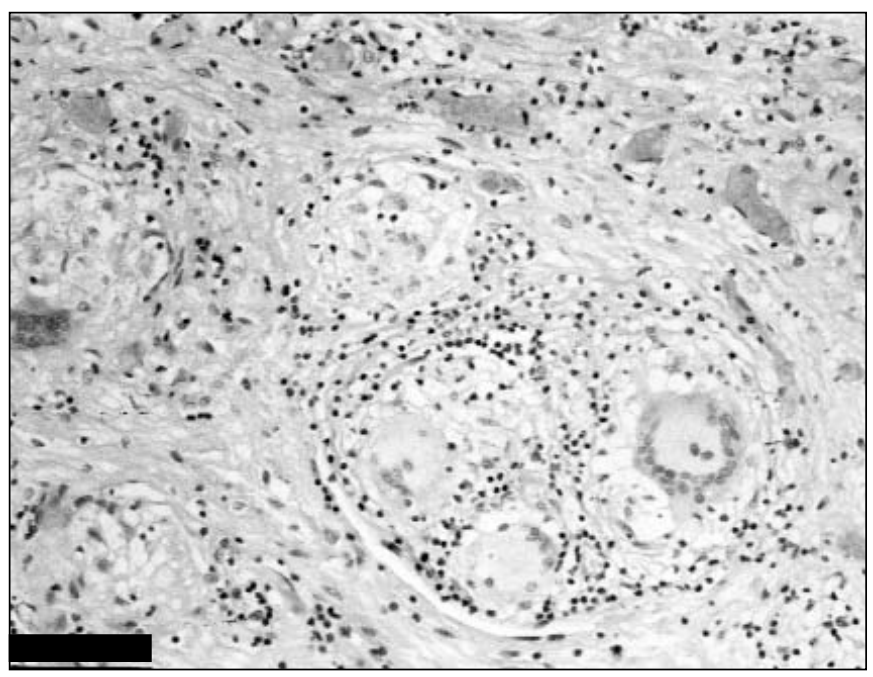

Figure 4: Granuloma with prominent multinucleated giant cells. Haematoxylin and eosin. Scale bar $100 \mu \mathrm{m}$. 
Table: Cases of Biopsy Proven Intramedullary Spinal Cord Sarcoidosis Without Systemic Involvement

\begin{tabular}{llll} 
Author & Cord Level & Treatment & Outcome \\
Jefferson '57 & C3-C4 & Biopsy & Dead \\
Garcin '62 & T12-L1 & Subtotal removal and steroids & Improved \\
Hitchon '84 & T5-T8 & Total removal and steroids & No change \\
Rubenstein '84 & C3-C6 & Biopsy and steroids & No change \\
Vighetto '85 & C5-C6 & Biopsy and steroids & Improved \\
Kelly '88 & C3-C6 & Biopsy and steroids & Improved \\
Levivier'91 & C3-C4 & Subtotal removal and steroids & No change \\
Kayama '93 & C3-C7 & Subtotal removal and steroids & No change \\
Kayama '93 & C3-C7 & Subtotal removal and steroids & Improved \\
Jallo '97 & C3-C6 & Biopsy and steroids & Improved \\
Jallo '97 & C2-C5 & Biopsy and steroids & Improved \\
Chitoku '97 & C6-T1 & Biopsy and steroids & Improved \\
Lee '98 & C4-C7 & Biopsy and steroids & Improved \\
Lee '98 & C1-C5 & Subtotal removal and steroids & Worse \\
Present case & C5-C6 & Subtotal removal and steroids & Improved \\
\hline
\end{tabular}

Sarcoidosis can present with clinical features suggesting meningeal involvement, or as an extramedullary intramedullary cord lesion.

Surgery is undertaken for biopsy and histopathologic diagnosis. ${ }^{5,6}$ The mainstay of treatment is high dose corticosteroid therapy. $5,6,8,10,41,52$ Radical surgical removal has been associated with worsening of neurological status, $4,5,8,11$ because of the infiltrative nature, and hence the difficulty achieving total resection of the lesion. Corticosteroid therapy has been effective in reducing the size of the lesion, evidenced by MRI and improving clinical outcome, although complete recovery is rare. ${ }^{6,25,43}$ Dose and duration of steroid therapy has not been defined. Reports suggest short-term improvement with steroid dose of $60 \mathrm{mg}$ od for several weeks followed by tapering over a few months, although others have found relapses with short course treatment. ${ }^{6,41}$ Hashmi $^{41}$ used $60 \mathrm{mg}$ of prednisone daily for one year followed by a second year of lower doses. Higher doses have been used for a short period with good results, however, a standardized approach has not been formulated. Other pharmacologic therapy (with variable results) includes methotrexate, cyclophosphamide, cyclosporine, axathioprine, chlorambucil, chloroquine and hyroxychloroquine. ${ }^{55}$

Our patient showed clinical improvement, while receiving corticosteroid treatement, prior to histopathologic diagnosis but relapsed when steroid dose was decreased. Once the histopathologic diagnosis was made, reinstitution of high dose steroid therapy resulted in improvement. Complications of steroid therapy, including marked weight gain and diabetes mellitus necessitated decreasing doses of steroid.

Other pharmocologic agents have been used in patients with central nervous system sarcoidosis, particularly when there is need to limit steroids. Stern reported success with cyclosporine in a steroid resistant patient with CNS neurosarcoidosis. ${ }^{54}$

Radiation therapy for brain lesions has also been undertaken with some measure of success. ${ }^{56-58}$ This therapy remains to be investigated for spinal cord sarcoidosis.

\section{Conclusion}

Sarcoidosis affecting the spinal cord is an exceptionally rare condition. It can mimic a neoplastic lesion, and therefore, pose a diagnostic and therapeutic challenge. Corticostoeroids are the principal mode of treatment. Alternative pharmocologic agents, other than steroids, may be an option in the future.

\section{REFERENCES}

1. Day AL, Sypert GW. Spinal cord sarcoidosis. Ann Neurol 1977;1:79-85.

2. Delaney P. Neurological manifestations in sarcoidosis: review of the literature, with a report of 23 cases. Ann Intern Med 1977;87:336345.

3. Siltzbach LE, James DG, Neville E. Course and prognosis of sarcoidosis around the world. Am J Med 1974;57:847-852.

4. Bogousslavsky J, Hungerbuhler JP, Regli F, Garf HJ. Subacute myelopathy as the presenting manifestation of sarcoidosis. Acta Neurochir (Wien) 1982;65:193-197.

5. Chitoku S, Kawai S, Watabe Y, et al. Multiple intramedullary spinal sarcoidosis: case report. Surg Neurol 1997;48:522-526.

6. Jallo GI, Zagzag D, Lee M, et al. Intraspinal sarcoidosis: diagnosis and management. Surg Neurol 1997;48:514-521.

7. Askanazy CL. Sarcoidosis of the central nervous system. J Neuropathol Exp Neurol 1952;11:392-400.

8. Banerjee T, Hunt WE. Spinal cord sarcoidosis. Case report. J Neurosurg 1972;36:490-493.

9. Barauh JK, Glausauer FE, Sil R, Smith BH. Sarcoidosis of the 
cervical spinal canal: case report. Neurosurgery 1978;3:216-218.

10. Bernstein J, Rival J. Sarcoidosis of the spinal cord as the presenting manifestation of the disease. South Med J 1978;71:1571-1573.

11. Buge A, Escourolle R, Poisson M, Rancurel G, Gray F. Sarcoidose medullaire: observation anatomo-clinique. Ann Med Interne (Paris) 1975;126:11-16

12. Campbell JN, Black P, Ostrow PT. Sarcoid of the cauda equina: case report. J Neurosurg 1977;47:109-112.

13. Clifton AG, Stevens JM, Kapoor R. Spinal cord sarcoidosis with intramedullary cyst formation. Br J Radiol 1990;63:805-808.

14. Collett P, Vighetto A, Bady B. Intramedullary sarcoidosis: an observation confirmed histologically. Presse Med 1983;40:25332534.

15. de Morsier G, Maurice P, Martin F. Besnier-Boeck diffus des muscles et lesions du systeme nerveux central. Acta Neurol Belg 1954;54:34-51.

16. Erickson TC, Odom G, Stern K. Boeck's disease (sarcoid) of the cental nervous system. Report of a case with complete clinical and pathologic study. Arch Neurol Psychiatric 1942;48:613-621.

17. Fazlullah S. Sarcoidosis with involvement of the nervous system. Dis Chest 1962;41:685-688.

18. Garcin R. Sarcoidose de la moelle lombo sacree. In: Bunge I (ed). Livre Jubilaire du Docteur Ludo van Bogaert. Bruxelles: Les Editions Acta Medica Belgica 1962: 301-309.

19. Hitchon PW, Haque AU, Olson JJ, Jacobs SK, Olson SP. Sarcoidosis presenting as an intramedullary mass. Neurosurgery 1984;15:8690.

20. Jefferson M. Sarcoidosis of the nervous system. Brain 1957;80:540556.

21. Kanoff RB, Ruberg RL. Intramedullary sarcoidosis of the spinal cord. Report of a case. J Am Osteopath Assoc 1978;77:868-873.

22. Kayama S, Kikuchi S. Intramedullary spinal cord sarcoidosis. Report of two cases. Spine 1993;18:2118-2120.

23. Kelly RB, Mahoney PD, Cowley KM. MR demonstration of spinal cord sarcoidosis. Report of a case. AJNR Am J Neuroradiol 1988;9:197-199.

24. Kinuta Y, Isaka F, Uemura Y, Kikuchi H. Two cases of spinal sarcoidosis. Spinal Surg 1994;8:147-151.

25. Lee M, Epstien FJ, Rezai AR, Zagzag D. Nonneoplastic intramedullary spinal cord lesions mimicking spinal cord lesions. Neurosurgery 1998;43(4):788-794.

26. Levivier M, Brotchi J, Balariaux D, Pirotte B, Durand JF. Sarcoidosis presenting as an isolated intramedullary tumor. Neurosurgery 1991;29:271-276.

27. Nishiura I, Tochio H, Koyama T. Cervical intramedullary sarcoidosis. Neurochirurgia 1992;35:163-166.

28. Riffel B, Wietholer H, Storh M, Thron A, Eggert R. Zur Sarkoidose des Ruckenmararks. Forschr Neurol Psychiatr 1982;50:275-278.

29. Rubenstien I, Hess J, Baum GL. Intramedullary spinal cord sarcoidosis. Surg Neurol 1984;21:272-274.

30. Semins H, Nugent GR, Chou SM. Intramedullary spinal cord sarcoidosis. Case report. J Neurosurg 1972;37:233-236.

31. Snyder R, Towfighi J, Gonatas NK. Sarcoidosis of the spinal cord. J Neurosurg 1976;44:740-743.

32. Vighetto A, Fischer G, Collet P, Bady B, Trillet M. Intramedullary sarcoidosis of the cervical spinal cord. J Neurol Neurosurg Psychiatr 1985;48:477-479.

33. Waxman JS, Hollenburg S. The spectrum of central nervous system sarcoidosis. A clinical and pathologic study. Mt Sinai J Med 1979;46:309-317.

34. Wiederholt WC, Siekert RG. Neurological manifestations of sarcoidosis. Neurology 1965;15:1147-1154.

35. Wood EH, Bream CA. Spinal sarcoidosis. Radiology 1959;73;226233.

36. Bogousslavsky J, Hungerbuhler JP, Regli F, Garf HJ. Subacute myelopathy as the presenting manifestation of sarcoidosis. Acta Neurochir (Wien) 1982;65:193-197.

37. Caroscio JT, Yahr MD. Progressive myelopathy due to sarcoid. Clin Neurol Neurosurg 1980;84:217-222.

38. Colover J. Sarcoidosis with involvement of the nervous system. Brain 1948;71:451-475.

39. Gallenkamp U, Suchenwirth R. Spinale Sarkoidose. Z Neurol 1971;200:274-278.

40. Goebel G. Myelitis transversa als Fruhmanifestations einer sarkoidose. Nervenarzt 1975;46:688-689.

41. Hashmi M, Kyritsis AP. Diagnosis and treatment of intramedullary spinal cord sarcoidosis. J Neurol 1998;245:178-180.

42. Kahan A. Sarcoidosis with involvement of the central nervous system. Proc Roy Soc Med 1952;45:509.

43. Kirks DR, Newton TH. Sarcoidosis: a rare cause of spinal cord widening. Radiology 1972;102:643.

44. Longscope WT, Freiman DG. Sarcoidosis or Besnier-BoeckSchaumann disease. JAMA 1941;117:1321-1327.

45. Moldover A. Sarcoidosis of the spinal cord. Arch Int Med 1958;102:414-417.

46. Okansen V. Neurosarcoidosis: clinical presentations and course in 50 patients. Acta Neurol Scand 1986;73:283-290

47. Pennell WH. Boeck's sarcoid with involvement of the central nervous system. Arch Neurol Psychiat 1951;66:728-737.

48. Ravindra NM, Chase PH, Elguezabel A, Weinstein M. Spinal cord sarcoidosis. NY State J Med 1976;766:748-752.

49. Reisner D. Boeck's Sarcoid and systemic sarcoidosis. Study of 35 cases. Am Rev Tuberculosis 1944;49:249-309.

50. Strickland GT, Moser KM. Sarcoidosis with a Landry-GuillianBarre syndrome and clinical response to corticosteroids. Am J Med 1967;43:131-135.

51. Walker A. Sarcoidosis of the brain and spinal cord. Postgrad Med J 1961;37:431-436.

52. Lexa FJ, Grossman RI. MRI of sarcoidosis in the head and spine: spectrum of manifestations and radiographic response to steroid therapy. Am J Neuroradiol 1994;15:973-982.

53. Sharma OP. The treatment of sarcoidosis: if not corticosteroids, then what? Pulmonary Perspectives 1997;14:141-143.

54. Stern BJ, Schonfeld SA, Sewell C, et al. The treatment of neurosarcoidosis with cyclosporine. Arch Neurol 1992;49:1065-1072.

55. Jarniero D, Seriés C. Les Neurosarcoidoses: revue de la Littérature. Neurochirurgie 1999;453:214-218.

56. Agbogu N, Stern BJ, Sewell C, Yang G. Therapeutic considerations in patients with refractory neurosarcoidosis. Arch Neurol 1995;52:875-879.

57. Bejar JM, Kerby GR, Ziegler DK, Festoff BW. Treatment of central nervous system sarcoidosis with radiotherapy. Ann Neurol 1985; 18:258-260.

58. Grizzanti JN, Knapp AB, Schecter AJ, Williams MH. Treatment of sarcoid meningitis with radiotherapy. Am J Med 1982;73:605608. 